\title{
BIODIESEL PRESENCE EFFECT ON THE THERMAL AND THERMO-OXIDATIVE STABILITY OF ITS BLENDS WITH DIESEL OIL
}

\author{
Tatiana Fernandes de Oliveira ${ }^{1,2} *$ e Jo Dweck ${ }^{1,2}$ \\ ${ }^{1}$ Programa de Tecnologia de Processos Químicos e Bioquímicos, Escola de Química, \\ Universidade Federal do Rio de Janeiro,219441-909 Rio de Janeiro, RJ \\ ${ }^{2}$ LABAT - Laboratório de Análises Térmicas, Escola de Química, Escola de Química \\ Universidade Federal do Rio de Janeiro,219441-909 Rio de Janeiro - RJ. \\ E-mails: tati.fo@gmail.com; dweck@eq.ufrj.br;jodweck@yahoo.com.br
}

\begin{abstract}
Nowadays in Brazil the biodiesel commercialization has to comply with Law \#13.263, of March $23^{\text {rd }}, 2016$, which establishes in $7 \mathrm{vol} \%$, the minimum mandatory percentage of addition to diesel oil. This law also indicates that in the future, this percentage will tend up to $20 \%$ (B20). The main objective of this research is to analyze the effects of the presence of biodiesel on the thermal and thermo-oxidative stability temperatures of its blends with diesel oil, as well as on their ignition temperatures. This evaluation of alternative fuels for diesel engines was done using thermogravimetry (TG), derived thermogravimetry (DTG) and differential thermal analysis (DTA). The thermal stability was determined by the extrapolated onset temperature of the TG loss (onset temperature) in a nitrogen environment. The thermo-oxidative stability was determined in two ways: the first by the onset temperature of loss of mass in the TG curve in air and the second, by the onset of the oxidation in liquid phase given by the onset temperature of the first peak of DTA curve, from which, the auto-ignition temperature was also determined. The results indicate that the increase in biodiesel content influences directly the ignition delay of the blends, which occurs during analysis. The thermal and thermooxidative stability temperatures of the blends increase linearly with the added content of biodiesel indicating that heavier products are being formed by oxidation, which may cause problems in the diesel circulation and engine efficiency
\end{abstract}

Keywords: blends biodiesel/diesel, thermal stability, thermoxidative stability, ignition temperature. 


\section{INTRODUCTION}

The present study analyzes the differences on the thermal stability, on the oxidative behavior of the liquid phase and on the ignition temperatures of commercial samples of diesel oil and biodiesel (soybean, methyl route) and their blends in an inert environment and in air. The main objective is to evaluate the effect of biodiesel added content on those properties.

Used in combustion engines ignited by compression, diesel oil is a complex mixture of paraffinic, naphthenic and aromatic hydrocarbons, containing 10 to 22 carbon atoms per molecule. It is an oil fraction slightly denser than kerosene and boils from 250 to $400^{\circ} \mathrm{C}$. Different relative proportions of those three classes of hydrocarbons influence the properties of the final fuel. Although compounds such as sulfur, oxygen and nitrogen are present in small quantities in diesel, they have a great influence on its properties, such as density, viscosity, flash point and other ones [1,2].

Due to the worldwide appeal for fuel sustainability, sources derived from renewable energy are preferred. The development of studies and researches looking for alternative sources to replace the fossil fuels on a wide scale, it is important not only to increase the use of clean technologies but also to supply of energy demand, which increases every year. The biodiesel is into contexts combatting the causes of global warming and climate change, helping Brazil to maintain high levels of clean and renewable energies in its energy matrix. Nowadays in Brazil, $45 \%$ of the produced energy and $18 \%$ of the consumed fuels are already from renewable sources [3].

Biodiesel is an alternative fuel composed of alkyl esters of long chain carboxylic acids derived from renewable sources. From the energy point of view, composition characteristics, such as free sulfur, high calorific value and biodegradability, are advantages which stimulate its use and reduce the $\mathrm{CO}_{2}$ emission which cause the biodiesel consumption to be more viable and attractive[4].

Blends of biodiesel and diesel oil tend to improve the characteristics of the petroleum derivatives increasing the lubricity, important for diesel oil of lower sulfur percentage [5]. The oxidation stability of biodiesel is the main parameter to ensure its quality, which is influenced by its chemical composition and physicochemical properties. However, the unsaturation degree in its chemical structure highly influences the oxidation stability at different levels [6].

The oxidation, from the point of view of chemical composition, can occur by organic substrates (unsaturated fatty acids), by hydrolysis and / or by reaction with oxygen [7]. The biodiesel has a chemical structure highly reactive, due to the presence of free radicals to generate unpaired electrons, which turn the molecule highly reactive [8]. Thus, volatile and non-volatile compounds are generated when increasing the oxidation rate, from the decomposition of formed peroxides [7].

According to Knothe et al. [6] the high biodiesel reactivity in oxidative environments is due to the presence of double bonds, fatty acids of the precursor oils, in the presence of water / air and metals. Often there is the formation of unstable hydro peroxides, which easily react generating secondary oxidation products, which cause operational problems and failures, affecting the engine performance [9].

It is important to note that, although the analyses were done at heating rates well below those actually occurring in engines during diesel compression, the order of the degree of influence of the biodiesel content on the thermal and the thermo-oxidative stabilities of 
respective blends is independent of the heating rate and actually increases in intensity, as the heating rate is increased [10]. Thus, the results of the present study can be used to predict the influence of the biodiesel content on the ignition delay that will occur in their use in real engines, reminding that the stability temperatures in engines will be higher, the higher will be the heating rate therein.

\section{MATERIALS AND METHODS}

\subsection{Materials}

Commercial samples of biodiesel from soy oil and diesel oil (diesel S-10A), which were in agreement with ASTM, ABNT and ISO standard characterization essays were used in this study. According to the supplier of these commercial samples their analyses were done following the Brazilian Resolution ANP number 45 of the 2014 [2]. The pure sample of diesel oil was called B0 and of the biodiesel, as B100. The biodiesel and diesel blends, which were prepared in the laboratory, were named as described in Table 1. All blends and raw materials were kept in a freezer to avoid oxidation during storage.

Table 1: Laboratory prepared blends

\begin{tabular}{lcc}
\hline Blend & $\begin{array}{c}\text { Diesel Oil } \\
(\text { vol\% })\end{array}$ & $\begin{array}{r}\text { Biodiesel } \\
(\text { vol\% })\end{array}$ \\
\hline B5 & 95 & 5 \\
B10 & 90 & 10 \\
B15 & 85 & 15 \\
B20 & 80 & 20 \\
\hline
\end{tabular}

\subsection{Methods}

Thermal analysis of the pure commercial products B0 and B100 and their blends (B5, B10, B15 and B20) were performed in a simultaneous thermogravimetric (TG) and differential thermal analysis (DTA) equipment, model SDT - Q600 from TA Instruments. The samples were heated from $25^{\circ} \mathrm{C}$ to $600^{\circ} \mathrm{C}$, using $5 \mathrm{mg}$ of mass in open aluminum crucibles at a heating rate of $10^{\circ} \mathrm{C} \cdot \mathrm{min}^{-1}$.

As purge and operation gases, nitrogen and air were used, respectively, for the analyzes in inert and oxidizing environments. The gas flow rate was $100 \mathrm{~mL} \cdot \mathrm{min}^{-1}$. A new aluminum crucible was always used for each analysis, supported on platinum support for equipment samples. This procedure was used to avoid that possible residues from a previous analysis could not interfere in the subsequent one. The data obtained by the TG and DTA curves were treated using the Universal Analysis software from TA Instruments [11], which also calculates and plots the thermogravimetry derivative curves (DTG). 


\subsubsection{Thermal Stability}

The thermal stability of a substance is obtained by the onset temperature (Tonset) of mass loss determined in a TG curve obtained at inert atmosphere conditions. The temperature is determined by the intersection of the tangents to the TG curve, passing by two points on the TG curve before and after the loss of mass. The point on TG curve after loss of mass, through which the second tangent is drawn, is the point at the temperature of the maximum of the DTG peak [11-13].

\subsubsection{Thermo-oxidative Stability}

In general the thermal stability temperature, determined as above, is considered as the extrapolated initial temperature at which the volatilization of the sample compounds begins. In case the sample is an organic fuel, which is submitted to an air environment, the components may suffer oxidation, the generated vapors may or not ignite, depending on the conditions such as pressure, concentration of the released components and oxygen content in the gaseous phase. The temperature of thermo-oxidative stability of the sample can be obtained by the onset temperature ( $\mathrm{T}_{\text {onset, } \mathrm{TG} \text {, oxvap }}$ ) of mass loss, wich is determined in the thermogravimetric curve (TG) at oxidizing atmosphere [1113 ,], in the same way that $\mathrm{T}_{\text {onset }}$ in inert ambient was determined, when the extrapolated temperature of the beginning of mass loss of volatiles under oxidizing conditions is desired.

However, Campello [14] found that in blends with biodiesel and lubricant oil, the

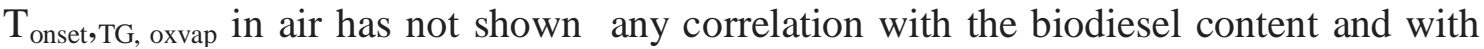
other conventional methods used to evaluate the oxidative stability of lubricant oils. On the other hand, he realized that the onset temperature of the first peak of the air

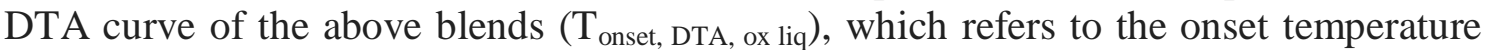
of the oxidation in the liquid phase, was in a much better correlation with the biodiesel content.

Therefore, in this work, the temperature $\mathrm{T}_{\text {onset, } \mathrm{DTA}}$, ox liq, indicated by Campello, was also determined, This temperature indicates in fact the onset temperature of the oxidation occurring in the liquid phase of each fuel or of the blends.

\subsubsection{Autoignition Temperature}

During dynamic thermal analysis using oxidative purge gases, such as air or pure oxygen, when sample organic component pyrolysis or cracking occurs, as the contents of released gases and temperature in the gaseous phase increase, the condition for the autoignition of the already released gas mixture is attained, promoting a sudden and very high exothermic effect [15], after which, the burnout of the following released gases is maintained.

This fact can be seen in DTA or in differential scanning calorimetry (DSC) curves, which allows one to determine the blend or fuel auto ignition temperature ( $\mathrm{T}$ autoign $)$ at the thermal analysis operating conditions. Thus this temperature is the onset temerature of the corresponding combustion exothermic DTA or DSC peak, which, usually is preceded by an endothermic effect of the vaporization or cracking transformation releasing the organic gases [15] 


\section{RESULTS AND DISCUSSION}

\subsection{Thermal Stability}

Figures 1 to 6 show the TG / DTG / DTA curves for biodiesel, diesel and their blends (B5, B10, B15 and B20) in an inert environment $\left(\mathrm{N}_{2}\right)$ as well as the respective thermal stability $\left(\mathrm{T}_{\text {onset }}\right)$ temperatures.

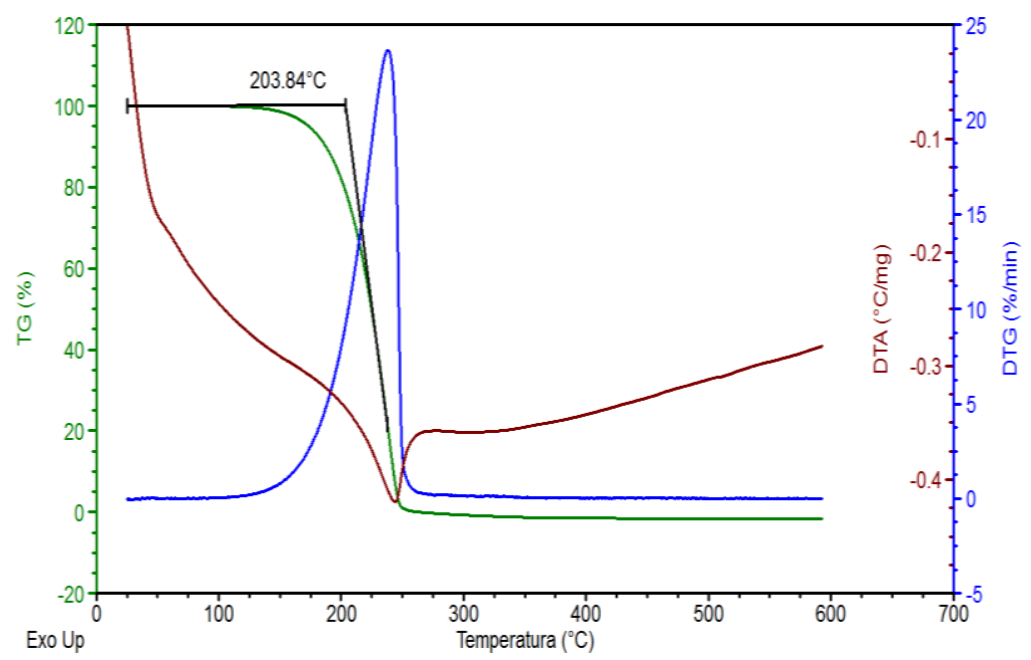

Fig.1: TG/DTG/DTA curves of biodiesel (B100) in an inert environment $\left(\mathrm{N}_{2}\right)$ at $10^{\circ} \mathrm{C} \cdot \mathrm{min}^{-1}$, with indication of respective thermal stability temperature

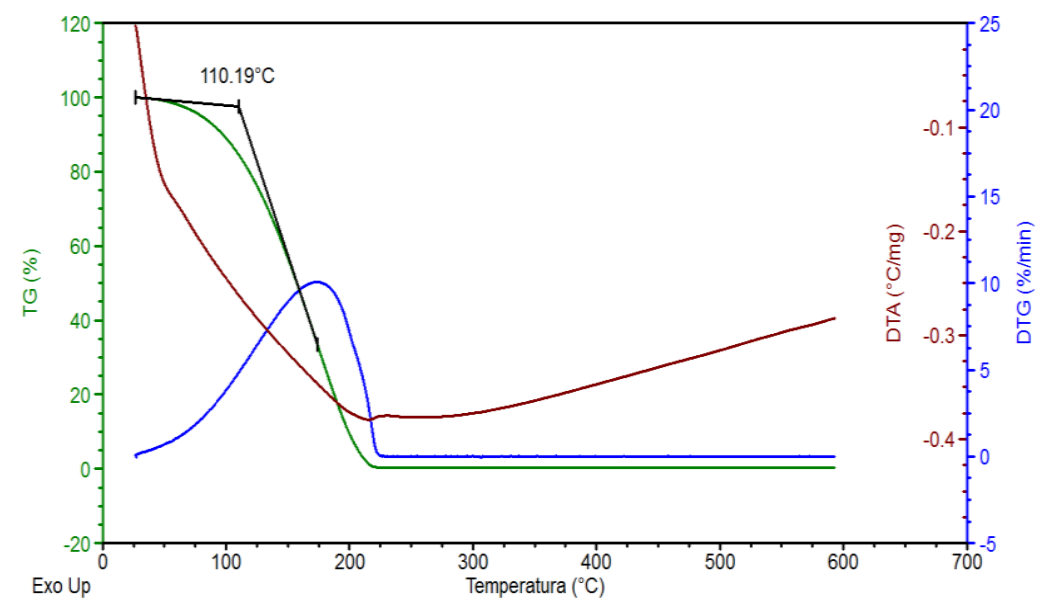

Fig. 2: TG/DTG/DTA curves of diesel oil (B0) in an inert environment $\left(\mathrm{N}_{2}\right)$ at $10^{\circ} \mathrm{C} \cdot \mathrm{min}^{-1}$, with indication of the respective thermal stability temperature

In Figures 1 and 2, from the TG / DTG / DTA curves of B100 and B0 respectively, it can be observed that the thermal stability of the diesel oil is much lower than that of biodiesel, since it has more volatile components. This also shows that biodiesel is thermally more stable than diesel oil, because it has esters in its composition, which have much lower vapor pressure than the light hydrocarbon fraction present in diesel. 


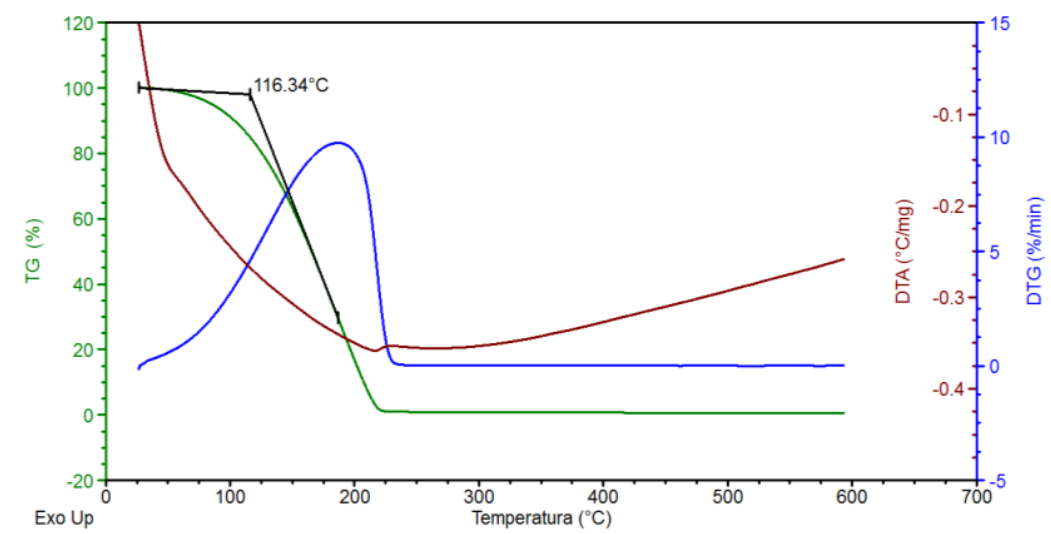

Fig. 3: TG/DTG/DTA curves of B5 in an inert environment $\left(\mathrm{N}_{2}\right)$, at $10^{\circ} \mathrm{C} \cdot \mathrm{min}^{-1}$, with indication of the respective thermal stability temperature

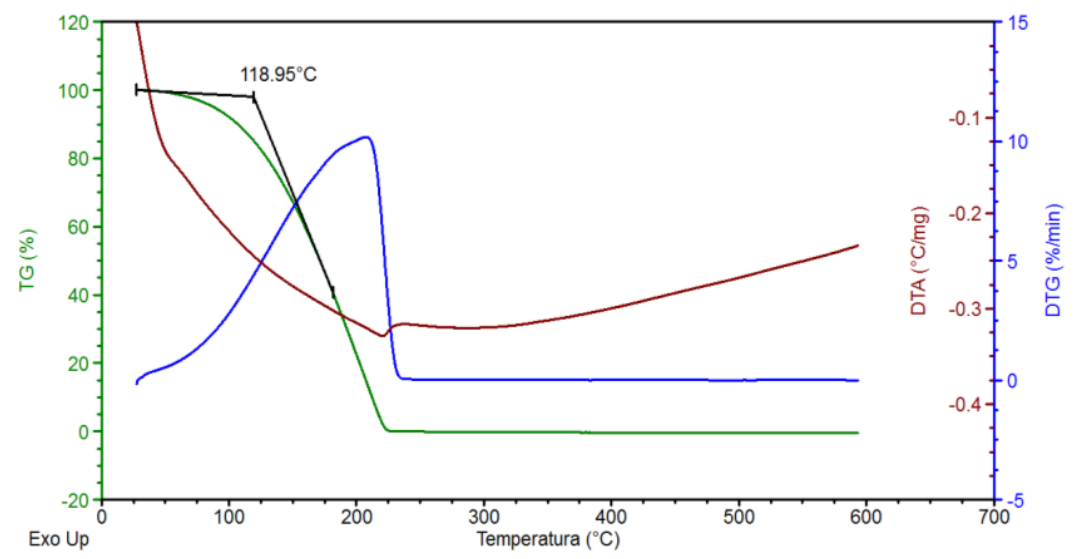

Fig. 4: TG/DTG/DTA curves of B10 in an inert environment $\left(\mathrm{N}_{2}\right)$, at $10^{\circ} \mathrm{C} \cdot \mathrm{min}^{-1}$, with indication of the respective thermal stability temperature

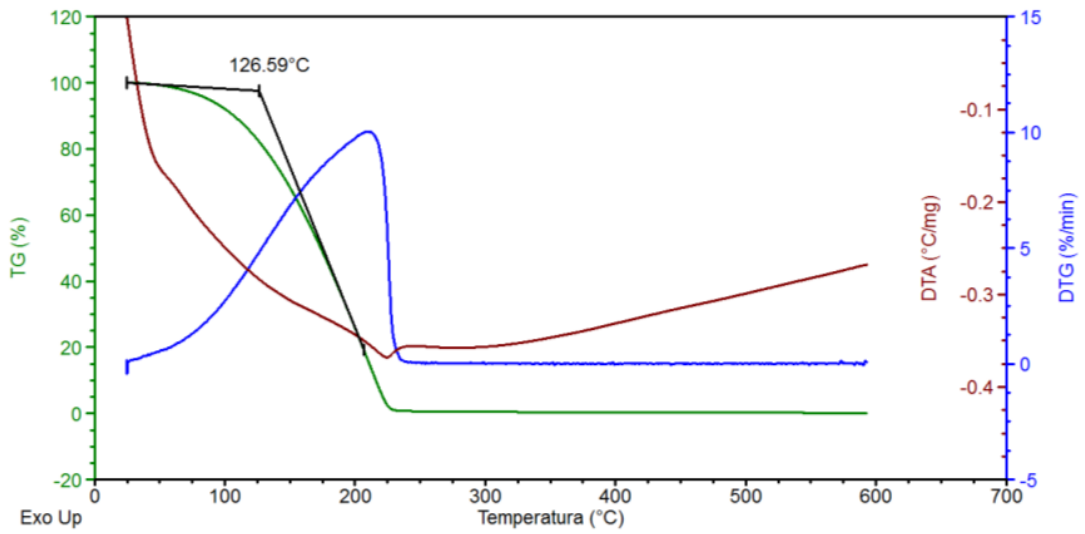

Fig. 5: TG/DTG/DTA curves of B15 in an inert environment $\left(\mathrm{N}_{2}\right)$, at $10^{\circ} \mathrm{C} \cdot \mathrm{min}^{-1}$, with indication of the respective thermal stability temperature 


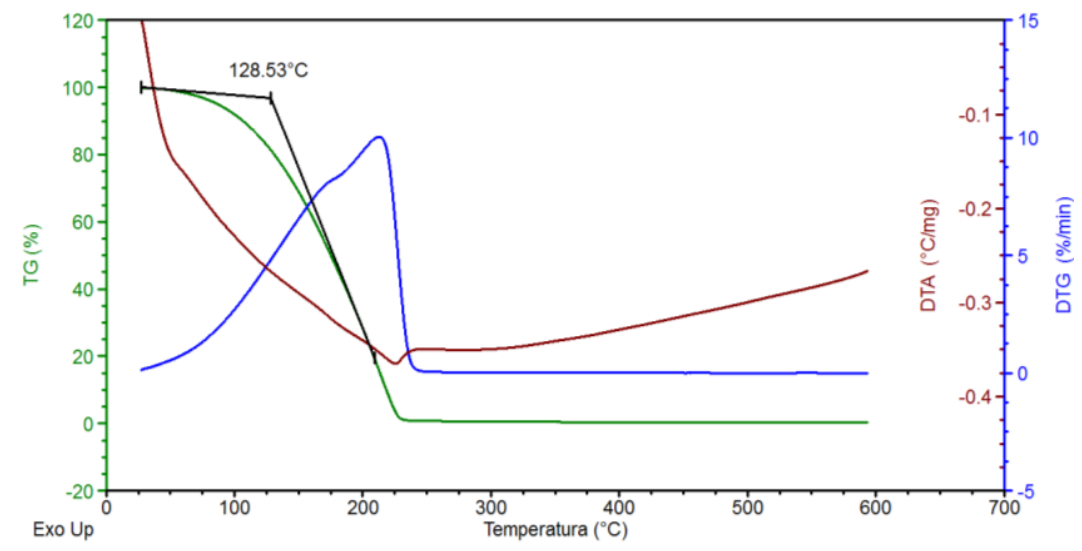

Fig. 6: TG/DTG/DTA curves of B20 in an inert environment $\left(\mathrm{N}_{2}\right)$, at $10^{\circ} \mathrm{C} \cdot \mathrm{min}^{-1}$, with indication of the respective thermal stability temperature

Figures 3 to 6 show that the thermal stability temperatures of the mixtures are higher than that of diesel oil (B0) showing that the percentage increase (in volume) of biodiesel increases the thermal stability of the blend, indicating that there is an interaction between the two fuels.

\subsection{Thermo-oxidative Stability and Autoignition Temperatures}

In Figures 7 and 8 the TG / DTG / DTA curves of diesel and biodiesel in air are shown. the $\mathrm{T}_{\text {onset TG, ox,vap, }} \mathrm{T}_{\text {onset, }} \mathrm{DTA}$, ox liq, thermo-oxidative stability temperatures, as well as the respective autoignition $\left(\mathrm{T}_{\text {autoign }}\right)$ temperatures, which occur at higher temperatures.

From the DTA curves, it can be observed that two exothermic peak are occurring. The first DTA peak, which occurs at lower temperatures, is due to the oxidation occurring in the liquid phase. The second DTA peak is due to combustion, which occurs at higher temperatures right after the autoignition temperature

Figure 7 shows the DTA curve of biodiesel in air, with an endothermic region followed by an exothermic peak which onset occurs at $178^{\circ} \mathrm{C}$ These two peaks indicate that volatilization of the components is occurring first, but is followed by the liquid phase oxidation phenomenon. Right after auto-ignition occurs at $253^{\circ} \mathrm{C}\left(\mathrm{T}_{\text {autoign }}\right)$, followed by combustion of the residual organics.

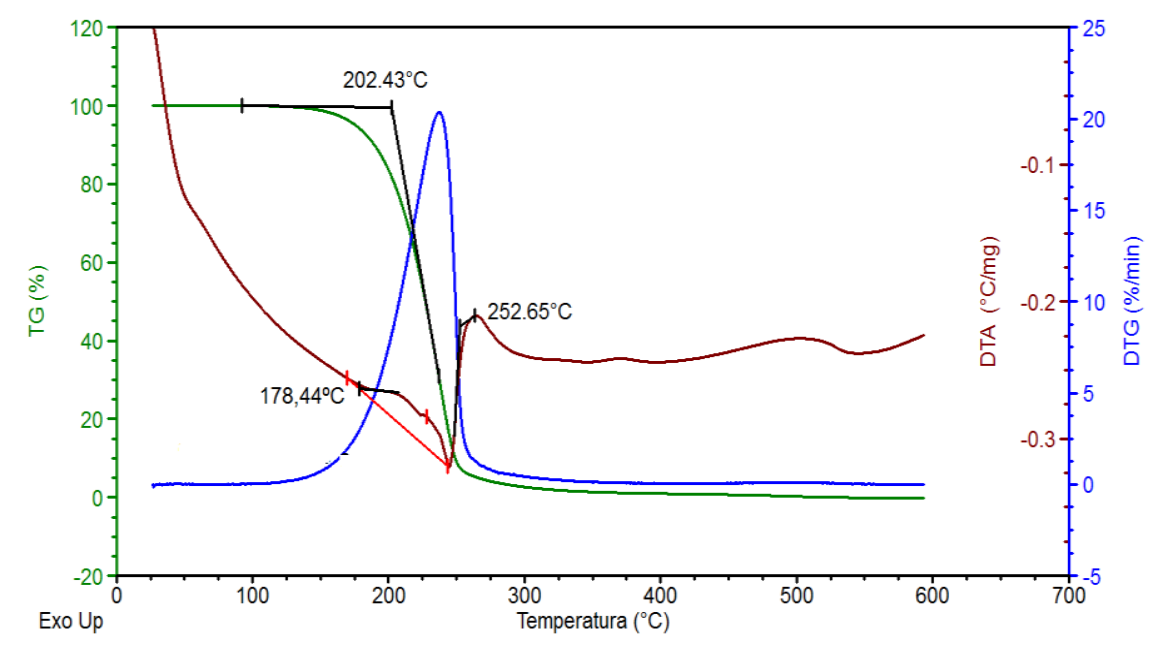

Fig. 7: TG/DTG/DTA curves, B100, in air , at $10^{\circ} \mathrm{C} \cdot \mathrm{min}^{-1}$, with indication of the $\mathrm{T}_{\text {onset, }}$ DTA, ox liq, $\mathrm{T}_{\text {onset } \mathrm{TG} \text { ox vap }}$ and $\mathrm{T}_{\text {autoign }}$ temperatures 
It should be noted that $\mathrm{T}_{\text {onset, DTA }}$ of biodiesel is $178^{\circ} \mathrm{C}$, which occurs before $\mathrm{T}_{\text {onset }} \mathrm{TG}$ ox vap, which in the case is $202^{\circ} \mathrm{C}$, , confirming the indication of Campello [14] that the Temperature $\mathrm{T}_{\text {onset, }}$ DTA, ox liq is the more suitable to evaluate the thermo-oxidative stability of biodiesel.

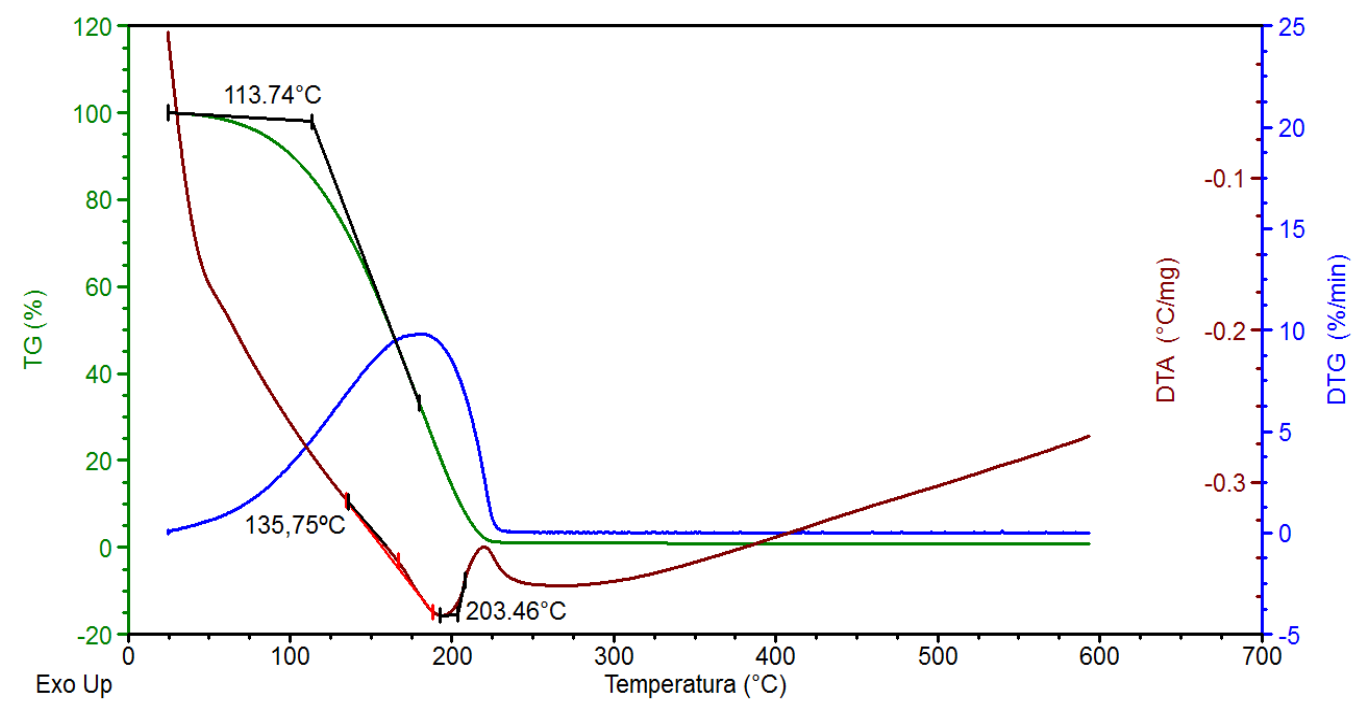

Fig. 8: TG/DTG/DTA curves, B0, in air , at $10^{\circ} \mathrm{C} \cdot \mathrm{min}^{-1}$, with indication of $\mathrm{T}_{\text {onset, } \mathrm{DTA} \text {, ox liq }}, \mathrm{T}_{\text {onset TG ox vap }} \mathrm{e} \mathrm{T}_{\text {autoign }}$ temperatures

When analyzing B0 (pure diesel), in Figure 8, it can be observed that its $\mathrm{T}_{\text {onset }} \mathrm{TG}$ ox vap

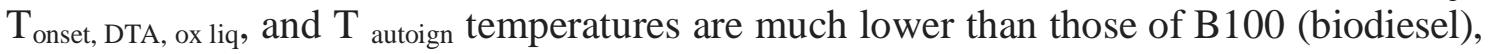
showing that for B0 its components are much more volatile and more easily oxidizable than those of the B100. This occurs because the latter consists of alkyl esters of long chain carboxylic acids that favor their oxidation at higher temperatures, while diesel oil is a complex mixture of paraffinic, naphthenic and aromatic hydrocarbons, with more volatile components oxidizable at lower temperatures, [17]

From Fig. 9 to 12, are shown the TG / DTG / DTA curves in air of the blends, with respective indication of their $\mathrm{T}_{\text {onset TG ox vap, }} \mathrm{T}_{\text {onset, }} \mathrm{DTA}$, ox liq and $\mathrm{T}_{\text {autoign }}$ temperatures. It can be seen that, in all these blends the higher content is of diesel components, which onset temperatures maintain the same order of appearance than in the diesel sample analyzed in air.

Thus in these blends, as in diesel sample case, the thermo-oxidative stability is given by the beginning of mass loss in air ambient as well, the oxidation in liquid phase occurring at higher temperatures. However comparing the onset temperatures of mass loss in nitrogen $\left(\mathrm{T}_{\text {onset }}\right)$ and in air ( $\mathrm{T}_{\text {onset }} \mathrm{TG}$ ox vap), the latter are little higher than the former, indicating that in air, some oxidation has occurred from the beginning of the analysis, which delayed the beginning of mass loss of the more volatile oxidized components. 


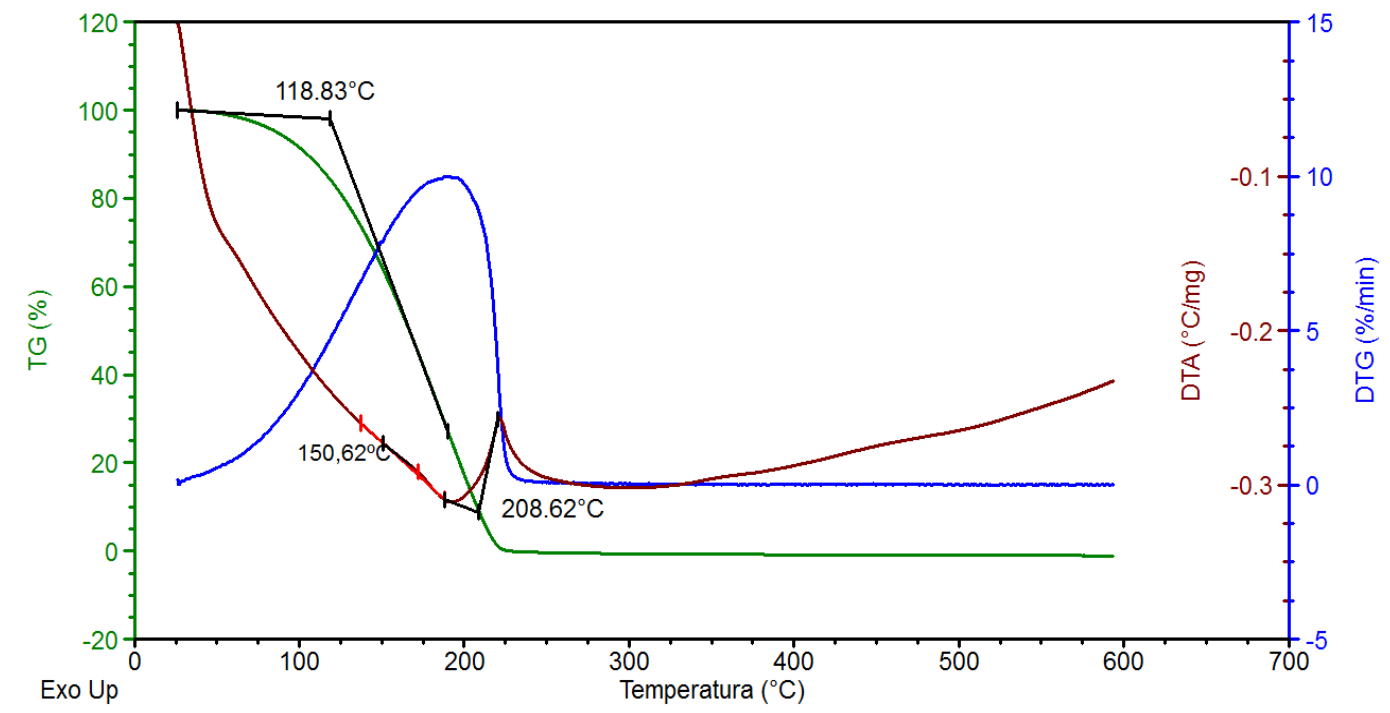

Fig. 9: TG/DTG/DTA curves of B5 blend, in air at $10^{\circ} \mathrm{C} \cdot \mathrm{min}^{-1}$, with indication of $\mathrm{T}_{\text {onset, DTA , ox liq }}, \mathrm{T}_{\text {onset TG ox vap }}$ and $\mathrm{T}_{\text {autoign }}$ temperatures

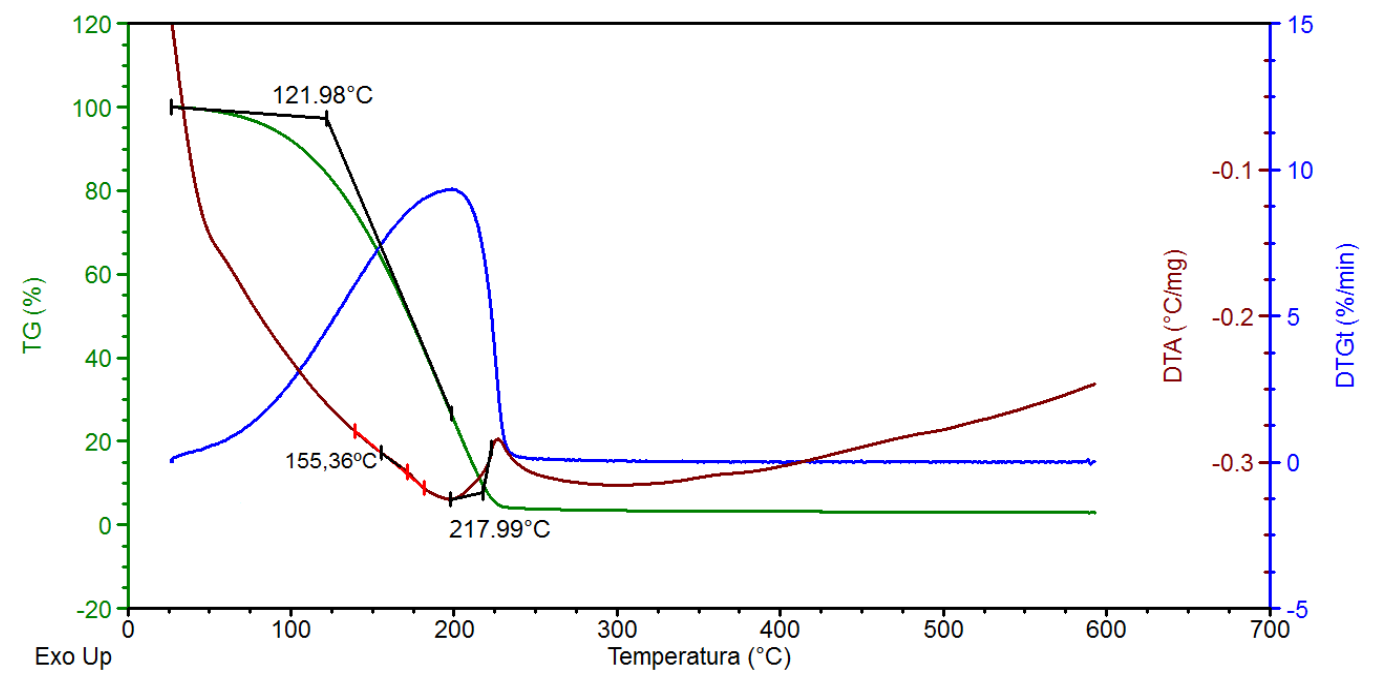

Fig. 10: TG/DTG/DTA, B10blend, in air , at $10^{\circ} \mathrm{C} \cdot \mathrm{min}^{-1}$ with indication of $\mathrm{T}_{\text {onset TG ox vap },} \mathrm{T}_{\text {onset, }} \mathrm{DTA}$, ox liq and $\mathrm{T}_{\text {autoign }}$ temperatures

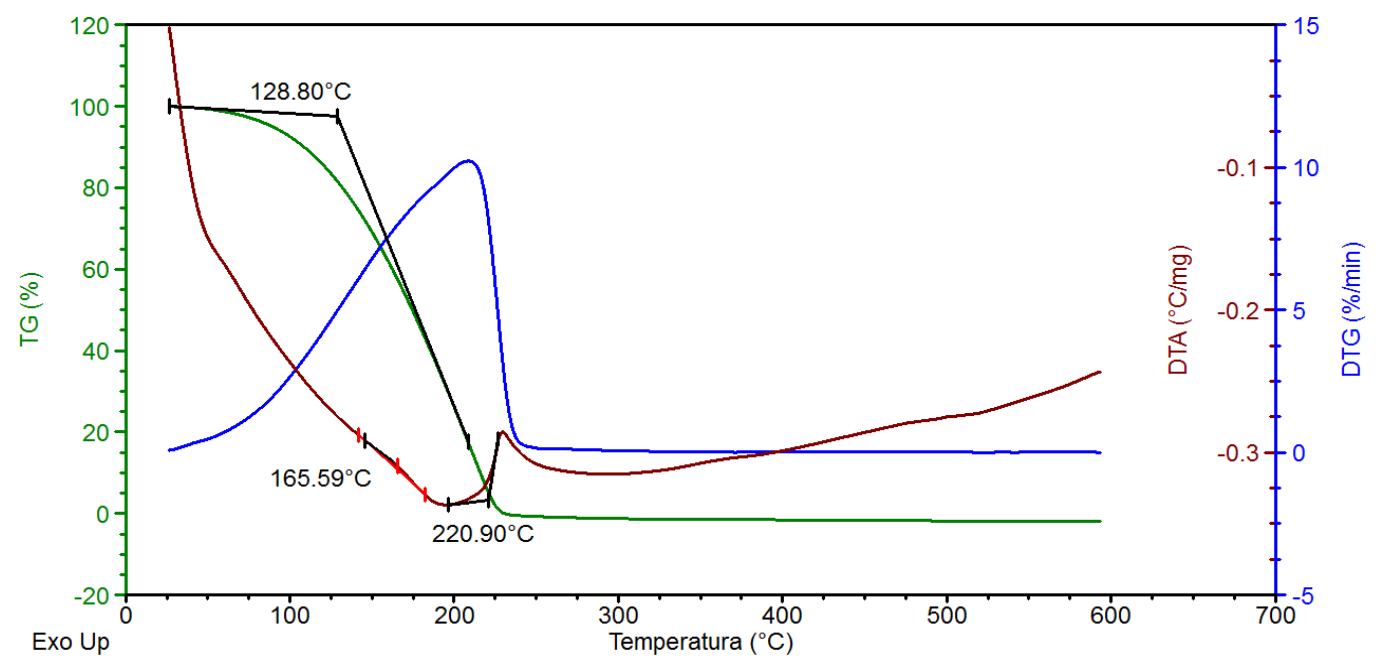

Fig. 11: TG/DTG/DTA curves, B15 blend, in air , at $10^{\circ} \mathrm{C} \cdot \mathrm{min}^{-1}$, with indication of $\mathrm{T}_{\text {onset TG ox vap }} \mathrm{T}_{\text {onset, }} \mathrm{DTA}$, ox liq , and $\mathrm{T}_{\text {utoign }}$ temperatures 


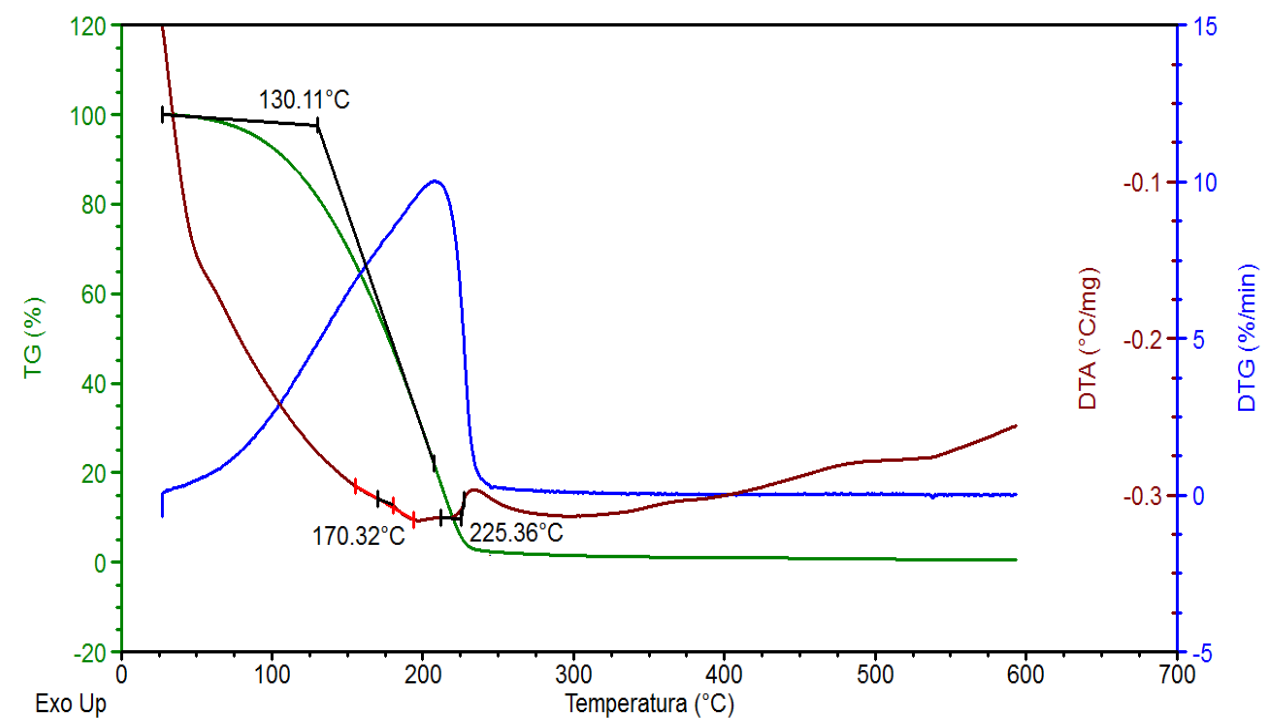

Fig. 12: TG/DTG/DTA curves, B20 blend, in air , at $10^{\circ} \mathrm{C} \cdot \mathrm{min}^{-1}$, ${ }^{1}$ with indication of $\mathrm{T}_{\text {onset TG ox vap },} \mathrm{T}_{\text {onset, } \mathrm{DTA}}$, ox liq and $\mathrm{T}_{\text {autoign }}$ temperatures

Figure 13 compares the determined onset temperatures in inert and oxidative ambients as a function of biodiesel volumetric content. As shown, in general, the thermooxidative stability temperatures are higher than those of thermal stability, what can be explained by the formation of heavier oxidized products in air.

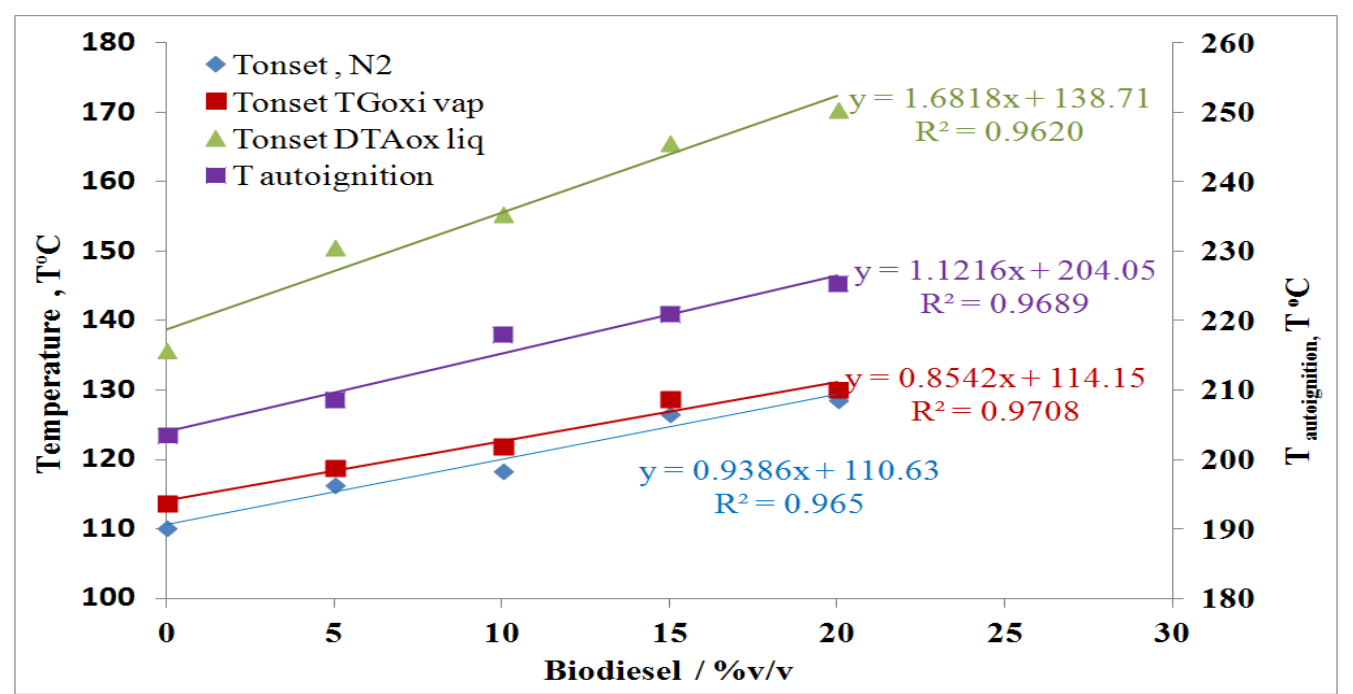

Fig.13: Thermal and thermo-oxidative stability temperatures of the blends as a function of biodiesel added content and respective auto-ignition temperatures

On the other hand, it is observed that the thermal and thermo-oxidative stability temperatures of the blends as well as those of their ignition points practically increase linearly as a function of the added biodiesel content to the diesel. This indicates a chemical interaction between these fuels and that greater problems with the formation of heavier products will occur in engines as the content increases. The angular coefficients of the respective trend lines show that the greatest influence of the addition of biodiesel 
occurs with the oxidation temperature in liquid phase. This fact indicates that the higher is the biodiesel content in the diesel the higher will be the ignition delay in diesel engines and the higher will be the possibility of residue formation.

\section{CONCLUSIONS}

- Although the thermal behavior of diesel is very different from that of biodiesel, since the former has more volatile and more easily oxidizable components than biodiesel, there is a chemical and physical interaction between them in their blends.

- The thermal stability of the blends, obtained from TG curve data in nitrogen, increases linearly with the added biodiesel content, due to the higher thermal stability of its esters.

- The thermo-oxidative stability of the blends obtained from TG curve data in air indicates that the temperatures required for volatilization of the oxidized lighter products increase linearly with the added biodiesel content, which may delay the ignition process.

- The thermo-oxidative stability temperature of the blend liquid phase obtained from the first DTA peak, indicates that the temperatures at which the heavier products form by liquid phase oxidation increase linearly with the biodiesel content added to the diesel.

- The previous occurrence may lead to the formation of heavier products, which may cause greater problems in the circulation of the blends in diesel engines.

- The ignition temperature increases linearly with the increase of biodiesel content in diesel, increasing the ignition delay of diesel engines, which may affect engine efficiency.

\section{REFERENCES}

[1] CHEVRON. Diesel Fuels Technical Review. Chevron Products Company, 1998. Disponível em:<www.chevron.com.br>.Acesso em 13 de março de 2017.

[2] ANP .Agência Nacional do Petróleo e Biocombustíveis. Disponível em: < www.anp.gov.br>. Acesso em $1^{\circ}$ de março 2017.

[3] Andrade, R.D.A. (2005). Dissertação de Mestrado: Calor de Combustão de blendas do tipo Diesel/Biodiesel e Diesel/Bio-óleo. Universidade de Brasília, Instituto de Química.

[4] Silva. I. (2009) . Uso de processos combinados para o aumento do rendimento de extração e da qualidade do óleo de macaúba. 99p. Dissertação de Mestrado, Curso de Tecnologia de Processos Químicos e Bioquímicos, Escola de Química, Universidade Federal do Rio de Janeiro.

[5] Penteado, M.C.P.S. (2005) . Identificação de gargalos e estabelecimento de um plano de ação para o sucesso do programa brasileiro do biodiesel. Ed.rev. São Paulo. 
[6] Knothe, G.,Gerpen, J. V., Krahl, J., Ramos, L. P. (2005). Manual de Biodiesel. São Paulo: Edgard Blucher, 340p. Traduzido por Luiz Pereira Ramos.

[7] List, G.R., Wang, T., Shukla, V. K.S. (2005). Storage, Handling, and Transport of Oils and Fats.Bailey's Industrial Oil and Fats products. Sixth Edition, Sic Volume Set. Edited by Fereidoon Shahidi.

[8] Lo, K.M., Cheung, P.C.K. (2005). Antioxidant activity of extracts from the fruiting bodies of Agrocybe awgerita var. Alba, Food chemistry, 89 (4) , 533-539.

[9] Monyem, A., Gerpen, J.V. (2001). The effect of biodiesel oxidatiom on engine performance and emissions . Biomass and Bioenergy, 20, 317-325

[10] Dweck, J. (2015). Fatores experimentais importantes em termogravimetria. Publicação interna do Curso de Análise térmica de Materiais e Processos, Curso de Tecnologia de processos Químicos e Bioquímicos, Escola de Química da UFRJ.

[11]T.A.Instruments -. Disponível em: <www.tainstruments.com>. Acesso em 6 dezembro de 2016.

[12] Dweck, J., Sampaio, C.S.M. (2004). Analysis of the Thermal Decomposition of Commercial Vegetable oils in air by simultaneous TG/DTA. J Thermal Anal Cal, 75, 385-391.

[13] Ionashiro, M., Caires, F.J., Gomes, D.J.C. (2014) Giolito: Fundamentos de Termogravimetria e Análise Térmica Diferencial / Calorimetria Exploratória Diferencial . Segunda Edição. São Paulo: Giz Editoral.

[14] Campello, M.L. (2014). Influência do Biodiesel na Estabilidade Termo-Oxidativa do Lubrificante. Dissertação de Mestrado, Curso de Tecnologia de Processos Químicos e Bioquímicos, Escola de Química, Universidade Federal do Rio de Janeiro. Orientador : Prof. Jo Dweck.

[15] Dweck, J. (2015). Oxidações e Combustão. Calorimetria Exploratória Diferencial, Publicação interna do Curso de Análise térmica de Materiais e Processos, Curso de Tecnologia de Processos Químicos e Bioquímicos, Escola de Química, Universidade Federal do Rio de Janeiro.

[16] Oliveira,T.F. (2012). Comportamento térmico de misturas diesel-biodiesel. Dissertação de Mestrado, Curso de Tecnologia de Processos Químicos e Bioquímicos, Escola de Química, Universidade Federal do Rio de Janeiro. Orientador: Prof. Jo Dweck.

[17] Kovac, O., Sarvan, V.,Skuljak, D. (2013). Influence of biodiesel in the oxidation stability of engine oils. Goriva i Maziva. 52(3), 219-23 